\section{Determination of heavy metals and selenium contents in fish meat sold at Erbil City, Kurdistan Region, Iraq}

\author{
Dhary Alewy Almashhadany, ${ }^{1}$ Hawraz \\ Sami Khalid, ${ }^{2}$ Hoshyar Saadi Ali ${ }^{1}$ \\ ${ }^{1}$ Pathological Analysis Department, \\ Knowledge University, College of \\ Science, Erbil City, Kurdistan Region; \\ ${ }^{2}$ Department of Chemistry, College of \\ Education, Salahaddin University-Erbil, \\ Erbil City, Kurdistan Region, Iraq
}

\begin{abstract}
Food contamination with heavy metals may pose a serious threat to human health. Fishes are the most common seafood globally. This study aimed to evaluate the levels of heavy metals in different fishes sold in Erbil city markets. The targeted heavy metal elements were cadmium (Cd), chromium $(\mathrm{Cr})$, cobalt $(\mathrm{Co})$, copper $(\mathrm{Cu})$, lead $(\mathrm{Pb})$, mercury $(\mathrm{Hg})$, manganese $(\mathrm{Mn})$, nickel $(\mathrm{Ni})$, selenium $(\mathrm{Se})$, and zinc $(\mathrm{Zn})$. Seventeen dorsal meat samples were digested and subjected to metal analysis by Inductively Coupled Plasma Optical Emission Spectrometry. Co, Mn, $\mathrm{Cu}$ and $\mathrm{Se}$ were detected in all samples, while cadmium was below the detectable level in all samples. The average concentrations of targeted trace elements were $0.03 \pm 0.016$, $0.02 \pm 0.03,0.07 \pm 0.08,0.10 \pm 0.08,0.03 \pm 0.03$, and $2.90 \pm 3.33 \mathrm{mg} / \mathrm{kg}$ for cobalt, chromium, copper, manganese, nickel, and zinc, respectively. Lead was only found in one sample $(5.88 \%)$. On the contrary, mercury was detected in all samples but in low concentration $(0.14 \pm 0.07)$. All detected heavy metals with specified permissible limits by $\mathrm{FAO} / \mathrm{WHO}$ were significantly lower than the permissible limits. Based on detected levels of targeted heavy metals, consumption of such fish has no potential risks to human.
\end{abstract}

\section{Introduction}

Industrial wastes, agricultural activities, and geochemical processes are the most potential sources for heavy metals pollution of environment including aquatic ecosystems (Rai, 2010). Deposition of large quantities of metals in marine bodies is a serious threat to aquatic livings and to other animals on the higher levels of various food chains. Deposition of such elements in humans also occur especially through consumption of contaminated seafood (Baki et al., 2018). Recently, the global consumption of fish has grown in parallel to the appreciation of their nutritional value. Indeed, fish meat contains essential minerals, vitamins, healthy unsaturated fatty acids, and high-quality proteins (Tilami and Sampels, 2018).

Heavy metal is a general term for a group of elements with density $>5 \mathrm{~g} / \mathrm{cm}^{3}$ (Ali and Khan, 2018). Heavy metals can be divided into two categories. The essential trace elements including chromium $(\mathrm{Cr})$, cobalt (Co), copper $(\mathrm{Cu})$, nickel $(\mathrm{Ni})$, manganese $(\mathrm{Mn})$, selenium $(\mathrm{Se})$, and zinc $(\mathrm{Zn})$. The second category is toxic metals and metalloids comprising cadmium (Cd), lead $(\mathrm{Pb})$, and mercury $(\mathrm{Hg})$. Essential trace elements, at low levels, are important for normal cellular processes, especially enzymatic reactions, in all living cells. Higher concentrations of these elements may result in toxicity and disruption of body homeostasis (Kennelly, 2018). On the contrary, no cellular functions for cadmium, lead, or mercury have been found. In fact, even very low concentrations of these elements can be toxic to cells.

Essential and nonessential elements have deleterious effects due to their bioaccumulative and non-biodegradable properties. There are two main routes by which heavy metals reach and accumulate in tissues of fish; ingestion of contaminated water or food, and via gills during respiration (Rajeshkumar and Li, 2018). Levels of heavy metals in fish reflects the levels of these elements in the water and the period of exposure (Annabi et al., 2013; Nhiwatiwa et al., 2011). Field and laboratory research have found the extent of accumulation in fish tissues is dependent on many factors including; the tissue, fish species, seafloor sediments, metal type, and water chemistry (Driscoll et al., 1994; Korkmaz Görür et al., 2012; Petrović et al., 2013). Additionally, age, sex, swimming pattern, reproductive cycle, and geographical location have all been found to contribute to the bioaccumulation extent (Rajeshkumar and Li, 2018)

Numerous studies have shown that high bioaccumulation culminated in sublethal effect and death in fish populations (Almeida et al., 2002; Jones et al., 2001; McGeer et al., 2000; Sakan et al., 2007; Zeitoun \& Mehana, 2014). Similarly, high concentrations of heavy metals in human cells may trigger different deleterious effects such as disruption of plasma membrane, deterioration of proteins and DNA, disruption of signal transduction systems, activating or inhibiting transcriptional
Correspondence: Dhary Alewy Almashhadany, Pathological Analysis Department, Knowledge University, College of Science, Erbil City, Kurdistan Region, Iraq

Tel.: 009647733565479.

E-mail: dhary.hammed@knowledge.edu.krd

Key words: Heavy metals; Kurdistan Region; selenium; fish; ICP-OES.

Conflict of interest: The authors declare no conflict of interest.

Funding: This study was supported by Knowledge University and Salahaddin University-Erbil.

Availability of data and materials: All data and materials are available within the text.

Received for publication: 11 December 2019. Revision received: 1 April 2020.

Accepted for publication: 2 April 2020.

This work is licensed under a Creative Commons Attribution-NonCommercial 4.0 International License (CC BY-NC 4.0).

(C) Copyright: the Author(s), 2020

Licensee PAGEPress, Italy

Italian Journal of Food Safety 2020; 9:8753

doi:10.4081/ijfs.2020.8753

factors, and generation of reactive oxygen species (Kim et al., 2019; Wu et al., 2016). These cellular injuries lead to systemic pathologies in the central nervous system, hematopoiesis, kidney function, immune system, respiratory and cardiovascular system (Kim et al., 2019).

Continuous emergence of reports addressing the health hazards of heavy metals compelled many global and regional legislative bodies to specify the accepted range for such metals in different foodstuff. World Health Organization and European Food Safety Authority have set maximum permissible limits for many heavy metals. The objective of this study was to investigate the content of some toxic heavy metals and selenium in different fish species outlined in Table 1 collected from markets in Erbil city.

\section{Materials and Methods}

\section{Reagents and chemicals}

All the used chemicals were of analytical grade. Nitric acid $(65 \% \mathrm{v} / \mathrm{v})$, hydrogen peroxide $\left(\mathrm{H}_{2} \mathrm{O}_{2} 50 \% \mathrm{v} / \mathrm{v}\right)$ (Scharlau, Extra Pure) and distilled water were used during digestion process and sample preparation. 


\section{Sample collection}

Seventeen different fish samples were purchased and collected for this investigation from different local markets in Erbil city, Kurdistan Region (Iraq) during Jun-July 2019. Dorsal muscle was selected as a major target tissue for metal analysis because muscle tissue is known as a main storage for metals and is the most appropriate part as a food. For each fish sample, muscle tissues were separated using stainless steel knife followed by cleansing, homogenization, labelling, and storage in polypropylene tubes in the refrigerator on the same day of collection.

\section{Sample preparation and digestion}

In this study, all samples were prepared and digested as previously published (Atobatele \& Olutona, 2015; Baharom and Ishak, 2015; Ismail and Saleh, 2012; Mendil et al., 2010). Briefly, dorsal muscle tissue was dried in an oven at $100^{\circ} \mathrm{C}$ for 12 hours till constant weights were obtained. Each dried sample was separately crushed and homogenized by using mortar. Then, one gram of each dried sample was transferred to a digestion conical flask. Each sample was treated with $5 \mathrm{~mL}$ of concentrated $\mathrm{HNO}_{3}(65$ $\%$ ) using a classic digestion-heater at $150^{\circ} \mathrm{C}$ for 20 minutes. After cooling, $3 \mathrm{~mL}$ of $\mathrm{H}_{2} \mathrm{O}_{2}$ (50\%) were added to each digestion conical flask. After completing digestion process, the mixture was cooled at room temperature and filtered. The filtrate was transferred to a conical flask and completed to $25 \mathrm{ml}$ with $0.1 \mathrm{~N} \mathrm{HNO}_{3}$ solution. Finally, the digested solution was kept in appropriate plastic bottles till analysis. Above steps were separately repeated three times for each sample and a blank. In order to prevent contamination, all equipment were cleaned and washed well with ultra-pure nitric acid before digestion process.

\section{Metal analysis}

Inductively Coupled Plasma Optical Emission Spectrometry (ICP-OES) instrument was used to determine the level of essential elements, cobalt (Co), chromium $(\mathrm{Cr})$, copper $(\mathrm{Cu})$, manganese $(\mathrm{Mn})$, nickel (Ni), selenium (Se), and zinc ( $\mathrm{Zn}$ ) content in digested samples. Non-essential elements; cadmium $(\mathrm{Cd})$, mercury $(\mathrm{Hg})$, and lead $(\mathrm{Pb})$ were also investigated. The estimated levels of these metals in each sample was measured in $\mathrm{ng} \cdot \mathrm{mL}^{-1}$ (parts per billion) and then converted to $\mathrm{mg} / \mathrm{kg}$ wet weight for fish tissues. Permissible limits set by WHO were employed in comparisons with detected levels in fish samples of the present study. The maximum permissible limits were extracted from (Baharom \& Ishak, 2015; Baki et al., 2018; CAC, 2019).

Limits of detection was calculated according to the following equation:

$$
L O D=3 R S D b \frac{C}{S B R}
$$

Where $\mathrm{RSDb}$ is the relative standard deviation of 10 replicates of the blank, $c$ is the concentration of the standard, and SBR is the signal to background ratio. Limits of detection and wavelength for each element are in Table 2. All relevant ICP operating parameters were software controlled, allowing easy selection of the optimum operating conditions according to manufacture instructions (https:// extranet.spectro.com/-/media/31793ADAB987-4D37-B597-04AFB66C7C22.pdf).

The accuracy and precision of the method

Table 1. Limits of detection (LOD) for the selected wavelengths (lines) for some elements.

\begin{tabular}{lcc}
\hline Element & Wavelength $(\mathrm{nm})$ & LOD $3(\mathrm{\mu g} / \mathrm{L})$ \\
$\mathrm{Co}$ & 228.615 & 0.654 \\
$\mathrm{Cr}$ & 267.716 & 0.67 \\
$\mathrm{Cu}$ & 324.754 & 1.1 \\
$\mathrm{Mn}$ & 257.610 & 0.08 \\
$\mathrm{Ni}$ & 231.604 & 0.95 \\
$\mathrm{Zn}$ & 213.856 & 0.2 \\
\hline $\mathrm{Cd}$ & 214.438 & 0.333 \\
$\mathrm{~Pb}$ & 220.351 & 3.44 \\
$\mathrm{Hg}$ & 184.950 & 1.1 \\
$\mathrm{Se}$ & 196.090 & 6.8 \\
\hline
\end{tabular}

Table 2. Characteristics of collected fish samples from Erbil city markets.

\begin{tabular}{|c|c|c|c|c|c|}
\hline $\mathbb{N}$ & Samples & Species & $\approx$ weight $(\mathrm{kg})$ & Origin & Status \\
\hline 1 & Daquq fish & Cyprinus carpio & 2.5 & Kirkuk, Iraq & Alive \\
\hline 2 & Daquq fish & Cyprinus carpio & 2 & Kirkuk, Iraq & Alive \\
\hline 3 & Daquq fish & Cyprinus carpio & 2 & Kirkuk, Iraq & Alive \\
\hline 4 & Taqtaq fish & Cyprinus carpio & 2.5 & Erbil, Iraq & Alive \\
\hline 5 & Taqtaq fish & Cyprinus carpio & 2 & Erbil, Iraq & Alive \\
\hline 6 & Taqtaq fish & Cyprinus carpio & 2.5 & Erbil, Iraq & Alive \\
\hline 7 & Dukan fish & Coregonus lavaretus & 1 & Sulaimani, Iraq & Alive \\
\hline 8 & Dukan fish & Coregonus lavaretus & 0.5 & Sulaimani, Iraq & Alive \\
\hline 9 & Dukan fish & Coregonus lavaretus & 2 & Sulaimani, Iraq & Alive \\
\hline 10 & Frozen fish & Pangasius bocourti & 2 & UAE & Frozen \\
\hline 11 & Frozen fish & Lethrinus nebulosus & 1 & UAE & Frozen \\
\hline 12 & Frozen fish & Rastrelliger kangurata & 1 & Turkey & Frozen \\
\hline 13 & Frozen fish & Stolephorus commersonnii & 0.025 & Turkey & Frozen \\
\hline 14 & Frozen fish & Pangasius bocourti & 2 & Thailand & Frozen \\
\hline 15 & Frozen fish & Lutjanus campechanus & 2 & Thailand & Frozen \\
\hline 16 & Frozen fish & Labeo rohita & 2 & Myanmar & Frozen \\
\hline 17 & Frozen fish & Clupea harengus & 1 & France & Frozen \\
\hline
\end{tabular}

UAE; United Arab Emirates. 
was investigated by analyzing the standard reference material SRM 1640 (Trace Elements in Natural Water). The measured value and the certified values were in excellent agreement for all elements.

\section{Statistical analysis}

Results of the study were subjected to statistical significance using GraphPad Prism 6 program software. One-sample t test was employed to compare the levels of heavy metals to the maximum permissible limits. Pearson correlation coefficient was used to assess the relationship between fish weight and heavy metal load. Significance level was set to 0.05 .

\section{Results and Discussion}

A total of seventeen fish samples were collected from market in Erbil city between January and July 2019. Nine samples (52.94\%) were alive locally-bred carp fish, while the remaining samples were frozen products imported from foreign countries. Details of collected samples are summarized in Table 1. The weight of samples ranged from $2.5 \mathrm{~kg}$ to $0.025 \mathrm{~kg}$ with an average of $1.65 \pm 0.74 \mathrm{~kg}$.

\section{Total load of heavy metals in sam- ples}

The total load of heavy metals in samples is summarized in Figure 1. The average content of heavy metals in fish muscles is $4.14 \pm 3.35 \mathrm{mg} / \mathrm{kg}$ with a wide range; 0.91 to $12.78 \mathrm{mg} / \mathrm{kg}$. There is a significant difference between fish samples in terms of total content of targeted heavy metals $(p<0.001)$. Poor negative correlation has been observed between fish weight and total load of targeted heavy metals $\left(r^{2}=-\right.$
$0.25)$. The highest metal load was found in samples of Dukan type. The average load of heavy metals in Dukan fish $(9.15 \mathrm{mg} / \mathrm{kg})$ is approximately three-fold higher than observed load in Daquq fish $(3.6 \mathrm{mg} / \mathrm{kg}$ ) and two-fold higher than Taqtaq fish (5.21 $\mathrm{mg} / \mathrm{kg})$.

\section{Heavy metals levels}

Essential and non-essential elements that have been specified by FAO/WHO didn't exceed those limits (Table 3). Indeed, all of the detected metals were significantly lower than permissible limits $(p<0.001)$. Levels of trace metal in all samples are depicted in Figure 2 while levels of detected toxic metals and selenium are plotted in Figure 3. Nickel was detected only in $11.76 \%$ of sample (2/17). Levels of $\mathrm{Cu}$ and $\mathrm{Zn}$ were $0.07 \pm 0.08 \mathrm{mg} / \mathrm{kg}$ and $2.90 \pm 3.34 \mathrm{mg} / \mathrm{kg}$. These levels are, indeed, significantly lower than permissible limits of FAO/WHO, 3 $\mathrm{mg} / \mathrm{kg}$ and $40 \mathrm{mg} / \mathrm{kg}$, respectively $(\mathrm{p}<0.001)$.
On the other hand, cadmium was not detected in any sample, while lead $(\mathrm{Pb})$ was found only in one sample (5.88\%). However, mercury $(\mathrm{Hg})$ was found in all samples and ranged from 0.05 to $0.30 \mathrm{mg} / \mathrm{kg}$ with an average of $0.14 \pm 0.07 \mathrm{mg} / \mathrm{kg}$.

Zinc showed the highest level among targeted metals in all samples. This observation is in good agreement with a recent Nigerian study (Adebayo, 2017). In contrast, cadmium was below the detectable level in all samples, which is consistent with reports from Malaysia (Baharom \& Ishak, 2015; Ismail \& Saleh, 2012) and Ghana (Gbogbo et al., 2018). Yet, previous studies from Iraq have detected low levels of cadmium in different locales (Al -Jubouri and Salman, 2019; Mensoor and Said, 2018). Moreover, a significantly high level was reported from Sulaimani city (Rashed, 2012). The concentrations of $\mathrm{Cu}, \mathrm{Mn}$, and $\mathrm{Ni}$ observed in the current study are significantly lower that found in the

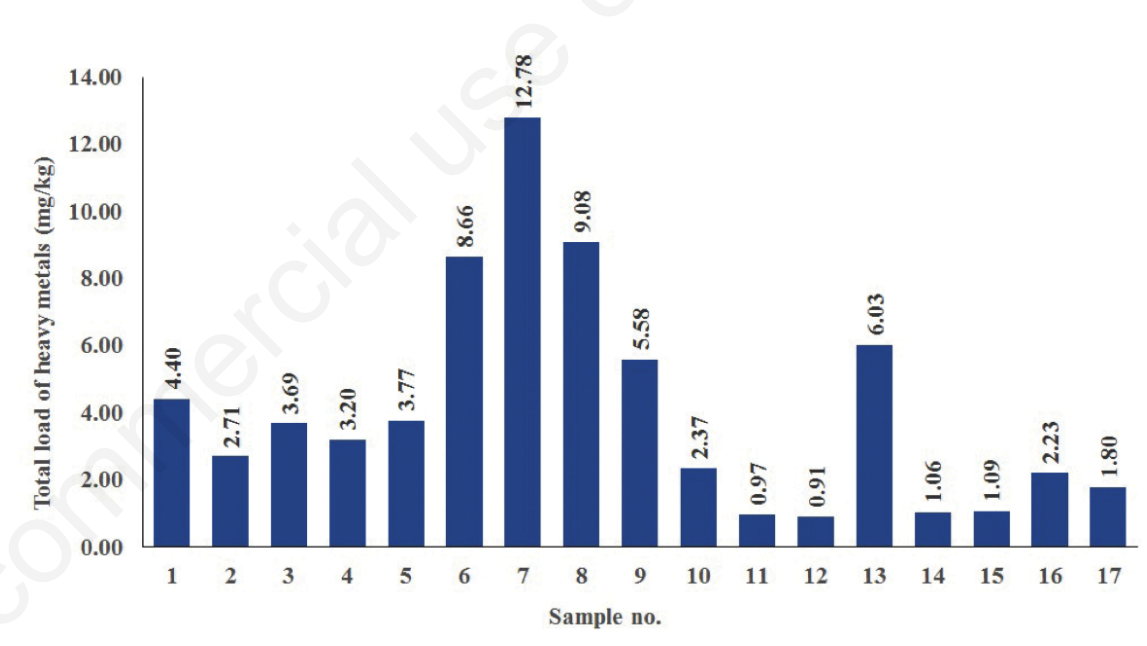

Figure 1. The total heavy metal load in fish samples.

Table 3. Comparison of mean concentration $(\mathrm{mg} / \mathrm{Kg}$ ) of heavy metals in fishes' sample in Erbil and other locations along with FAO/WHO standards.

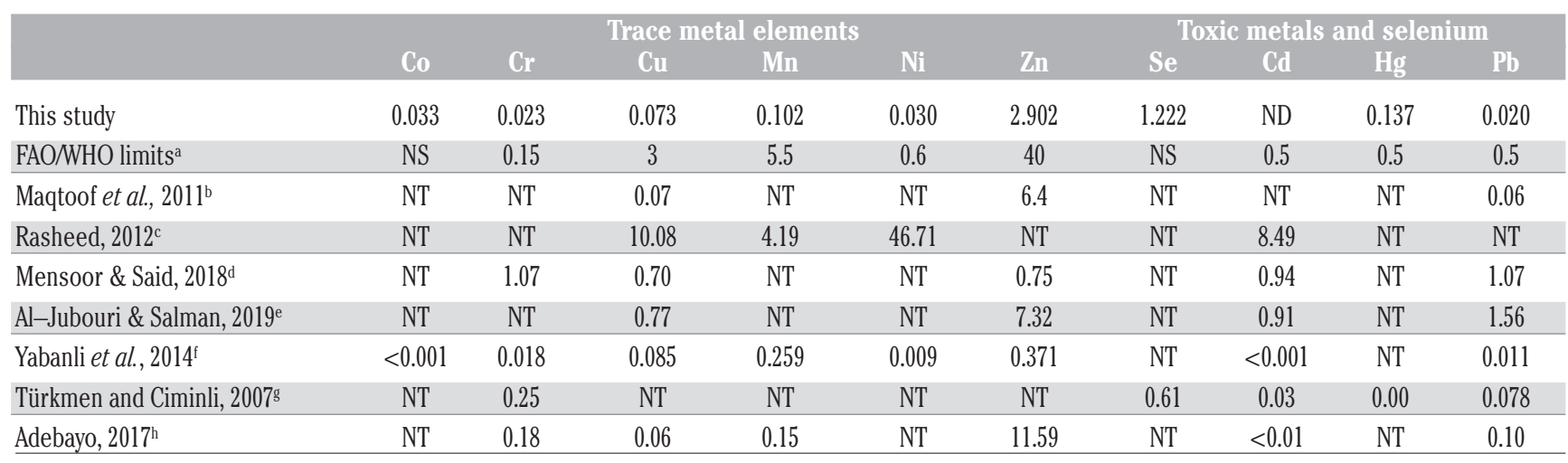

ND: not detected. NS: not specified. NT: not tested. apermissible limits extracted from various references (Tiimub \& Afua, 2013; Hashim et al., 2014; Baharom \& Ishak, 2015; Rajeshkumar \& Li, 2018) bsamples drawn

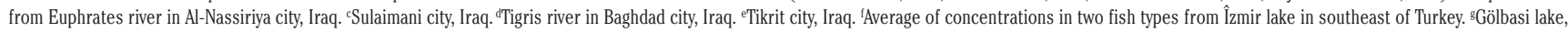
Turkey. "Ekiti city, Nigeria. 
mentioned study conducted in Sulaimani city. Such difference is subjected to factors such as difference fish species, contamination level in fish habitat, among others (Rajeshkumar and Li, 2018). The lead content found in this study is consistent with the results reported from some fish species in Nigeria (Atobatele and Olutona, 2015).

\section{Comparisons of heavy metals with other studies}

Variations in heavy metals levels between studies seemed to be attributed to the difference between fish species, and geographical location. Results reported from local, regional and other parts of the world are summarized in Table 3. It should be noted that scarce of studies evaluating the same heavy metals and fish species addressed in our study is an obvious limitation. The comparison made in Table 3 is somehow limited due to lack of data. The current data were incorporated for a rough comparison and hopefully to elicit further scientific investigations of the addressed species.
A)

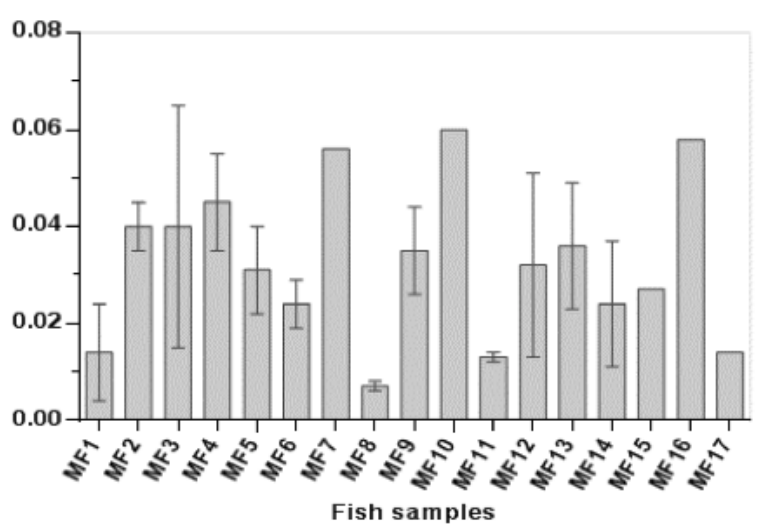

C)

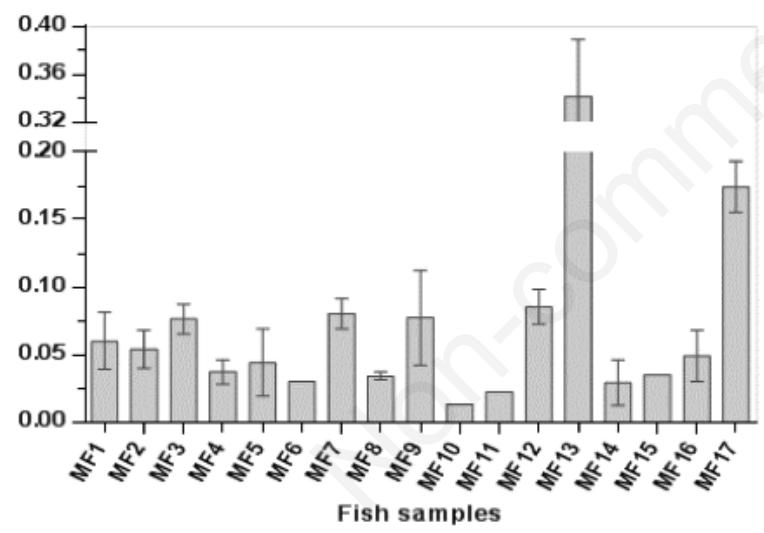

E)

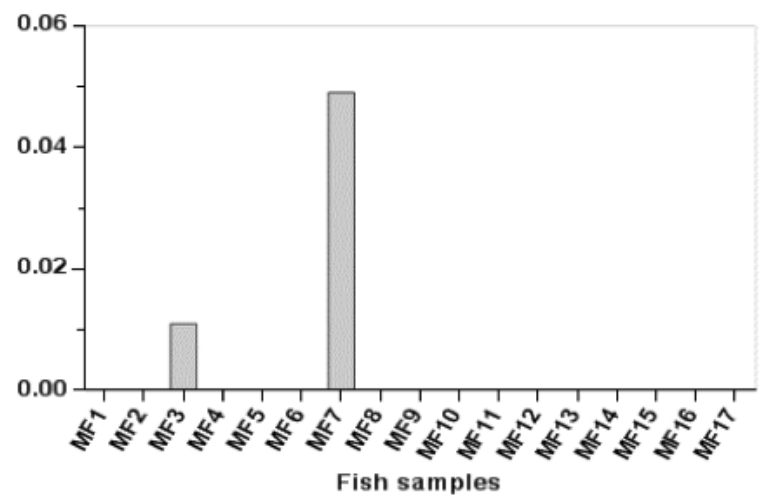

B)

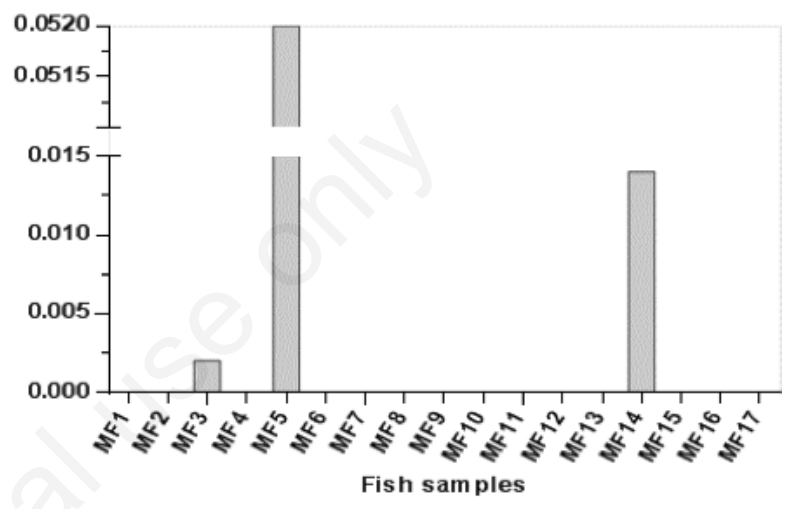

D)

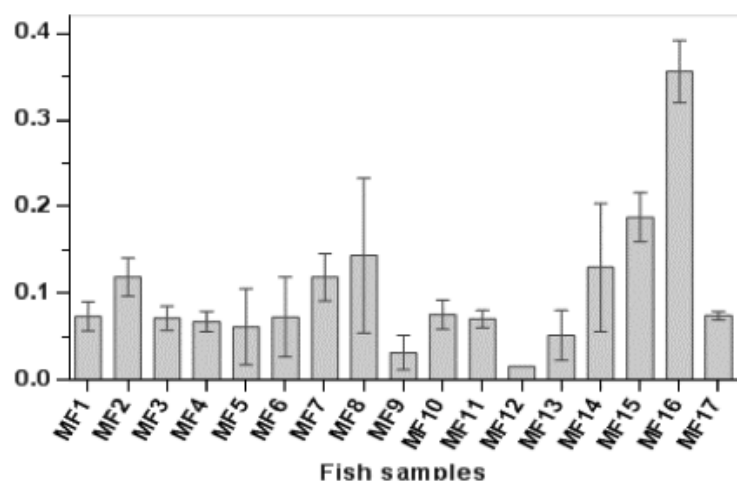

F)

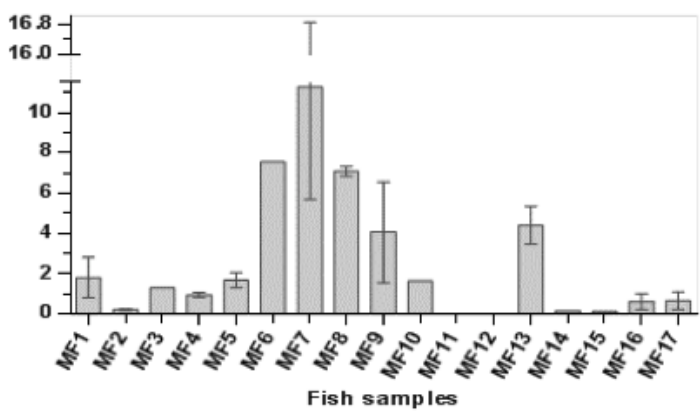

Figure 2. levels of trace elements in fish samples expressed in mg/kg. cobalt (A), chromium (B), copper (C), manganese (D), nickel (E), and zinc $(F)$. 
A)

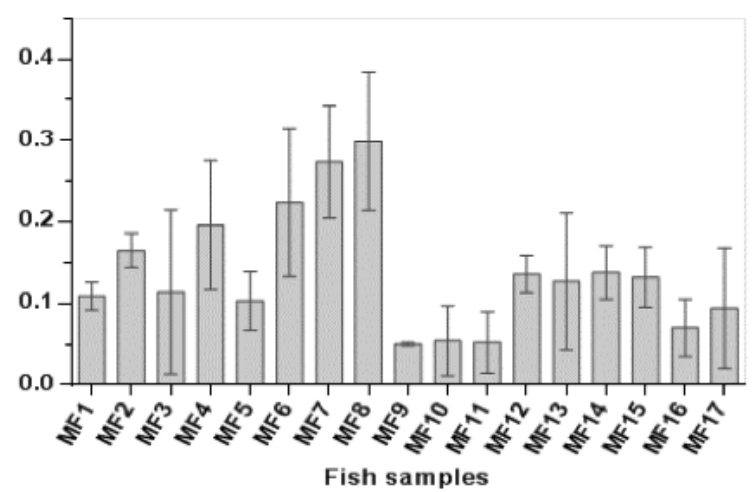

B)

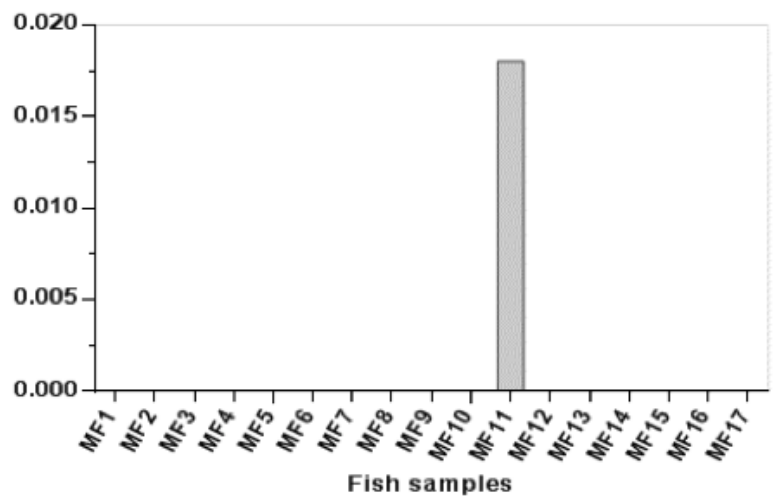

C)

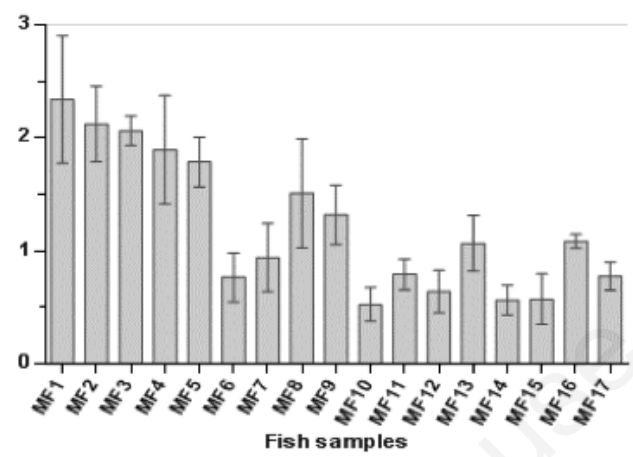

Figure 3. levels of detected toxic heavy metals and selenium in fish samples expressed in mg/kg. Mercury (A), lead (B), and selenium (C).

\section{Conclusions}

Toxic heavy metal contents detected in fish sold in Erbil city are significantly lower than the permissible limits of FAO/WHO. Since detected heavy metals didn't exceed the permissible limits, consumers have no potential risk of heavy metal toxicity.

\section{References}

Adebayo I, 2017. Determination of Heavy Metals in Water, Fish and Sediment from Ureje Water Reservoir. Fish \& Ocean Opj 4;1-5.

Al -Jubouri HFM, Salman SA, 2019. Different analytical methods for estimating the heavy metals in fish products available in the Iraqi local markets by atomic absorption technique. Tikrit J Pure Sci 24:18-24.

Ali H, Khan E, 2018. What are heavy metals? Long-standing controversy over the scientific use of the term 'heavy metals'-proposal of a comprehensive definition. Toxicol Environ Chem 100:6-19.

Almeida JA, Diniz YS, Marques SF, Faine
LA, Ribas BO, Burneiko RC, Novelli EL, 2002. The use of the oxidative stress responses as biomarkers in Nile tilapia (Oreochromis niloticus) exposed to in vivo cadmium contamination. Environ Int 27:673-9.

Annabi A, Said K, Messaoudi I, 2013. Cadmium: Bioaccumulation, Histopathology and Detoxifying Mechanisms in Fish. Am J Res commun 1:60-79.

Atobatele OE, Olutona GO, 2015. Distribution of three non-essential trace metals (Cadmium, Mercury and Lead) in the organs of fish from Aiba Reservoir, Iwo, Nigeria. Toxicol Rep 2:896-903.

Baharom ZS, Ishak MY, 2015. Determination of Heavy Metal Accumulation in Fish Species in Galas River, Kelantan and Beranang Mining Pool, Selangor. Procedia Environ Sci 30:320-5.

Baki MA, Hossain MM, Akter J, Quraishi SB, Shojib MF, Ullah AA, Khan MF, 2018. Concentration of heavy metals in seafood (fishes, shrimp, lobster and crabs) and human health assessment in Saint Martin Island, Bangladesh. Ecotoxicol Environ Saf 159:153-63.
CAC, 2019. General standard for contaminants and toxins in food and feed. CXS 193-1995. Amendment 2019.

Driscoll CT, Yan C, Schofield CL, Munson R, Holsapple J, 1994. The mercury cycle and fish in the Adirondack lakes. Environ Sci Technol 28:136A-43A.

Gbogbo F, Arthur-Yartel A, Bondzie JA, Dorleku WP, Dadzie S, Kwansa-Bentum B, Ewool J, Billah MK, Lamptey AM, 2018. Risk of heavy metal ingestion from the consumption of two commercially valuable species of fish from the fresh and coastal waters of Ghana. PLOS ONE 13, e0194682.

Hashim R, Song TH, Muslim NZ, Yen TP, 2014. Determination of heavy metal levels in fishes from the lower reach of the Kelantan River, Kelantan, Malaysia. Trop life sci Res 25:21-39.

Ismail I, Saleh IM, 2012. Analysis of heavy metals in water and fish (Tilapia sp.) samples from Tasik Mutiara, Puchong. Malaysian J Analytical Sci 16:346-52.

Jones I, Kille P, Sweeney G, 2001. Cadmium delays growth hormone expression during rainbow trout development. J Fish Biol 59:1015-22.

Kennelly P, 2018. The biochemical roles of 
transition metals. In: Rodwell $\mathrm{V}$, Kennelly P, Bender P, Weil P, Botham K, eds. Harper's Illustrated Biochemistry. McGraw-Hill, New York, pp 92-102.

Kim JJ, Kim YS, Kumar V, 2019. Heavy metal toxicity: An update of chelating therapeutic strategies. J Trace Elements in Med Biol 54:226-31.

Korkmaz Görür F, Keser R, Akçay N, Dizman S, 2012. Radioactivity and heavy metal concentrations of some commercial fish species consumed in the Black Sea Region of Turkey. Chemosphere 87:356-361.

Maqtoof AA, Mohammed AB, Al-Khafaji B, 2011. Distribution Of Some Heavy Metals In Water, Sediment \& Fish Cyprinus carpio in Euphrates River Near Al- Nassiriya City Center South Iraq. Baghdad Sci J 8:552-560.

McGeer JC, Szebedinszky C, McDonald DG, Wood. CM, 2000. Effects of chronic sublethal exposure to waterborne $\mathrm{Cu}, \mathrm{Cd}$ or $\mathrm{Zn}$ in rainbow trout. 1: Ionoregulatory disturbance and metabolic costs. Aquat Toxicol 50:231-243.

Mendil D, Ünal ÖF, Tüzen M, Soylak M, 2010. Determination of trace metals in different fish species and sediments from the River Yeşili\{dotless \}rmak in Tokat, Turkey. Food Chemi Toxicol 48:138392.

Mensoor M, Said A, 2018. Determination of
Heavy Metals in Freshwater Fishes of the Tigris River in Baghdad. Fishes 3:23. Nhiwatiwa T, Barson M, Harrison AP, Utete B, Cooper RG, 2011. Metal concentrations in water, sediment and sharptooth catfish Clarias gariepinus from three peri-urban rivers in the upper Manyame catchment, Zimbabwe. Afr J Aquat Sci 36:243-52.

Petrović Z, Teodorović V, Dimitrijević M, Borozan S, Beuković M, Milićević D, 2013. Environmental $\mathrm{Cd}$ and $\mathrm{Zn}$ concentrations in liver and kidney of European hare from different Serbian regions: Age and tissue differences. Bulletin Environ Contam Toxicol 90:203-7.

Rai PK, 2010. Heavy metal pollution in lentic ecosystem of sub-tropical industrial region and its phytoremediation. Int $\mathrm{J}$ Phytoremediation 12:226-42.

Rajeshkumar S, Li X, 2018. Bioaccumulation of heavy metals in fish species from the Meiliang Bay, Taihu Lake, China. Toxicol Rep 5:288-95.

Rashed RO, 2012. Assessment of some Heavy Metals in Muscle Tissue of Silurus triostegus from Derbendikhan Reservoir, Kurdistan Region -Iraq. Rafidain J Sci 23:11-8.

Sakan S, Gržetić I, Đorđević D, 2007. Distribution and fractionation of heavy metals in the Tisa (Tisza) River sediments. Environ Sci Pollut Res-Int 14:229-36.

Tiimub BM, Afua MA, 2013. Determination of selected heavy metals and Iron concentration in two common fish species in Densu River at Weija District in Grater Accra region of Ghana. Amer Int J Bio 1:45-55.

Tilami S, Sampels S, 2018. Nutritional Value of Fish: Lipids, Proteins, Vitamins, and Minerals. Rev Fisheries Sci Aquacult 26:243-53.

Türkmen M, Ciminli C, 2007. Determination of metals in fish and mussel species by inductively coupled plasma-atomic emission spectrometry. Food Chem 103:670-5.

Wu X, Cobbina SJ, Mao G, Xu H, Zhang Z, Yang L, 2016. A review of toxicity and mechanisms of individual and mixtures of heavy metals in the environment. Environ Sci Pollut Res 23:8244-59.

Yabanlı M, Yozukmaz A, Alparslan Y, Acar Ü, 2014. Evaluation of heavy metals and selenium contents in the muscle tissues of rainbow trout (Oncorhynchus mykiss Walbaum, 1792) in Western Anatolia. J Food, Agr Environ 12:165-8.

Zeitoun MM, Mehana E-SE, 2014. Impact of Water Pollution with Heavy Metals on Fish Health: Overview and Updates. Glob Vet 12:219-231. 